\title{
ОСОБЛИВОСТІ ВИЗНАЧЕННЯ РАЦІОНАЛЬНИХ ПЛОЩАДОК ДЛЯ РОЗМІЩЕННЯ ФОТОЕЛЕКТРИЧНИХ СТАНЦІЙ В УКРАЇНІ
}

\author{
Л.А. Кирнос, В.О. Пундєв, В.Ф. Рєзцов, чл.-кор. НАН України, Т.В. Суржик, канд. техн. наук, В.І. Шевчук, \\ І.О. Шейко
}

Інститут відновлюваної енергетики НАН України, Київ, вул. Гната Хоткевича 20а, м. Київ, 02094, Україна

Метою роботи є систематизачія та впорядкування дій та основних положень з урахуванням діючих нормативних документів, які необхідно виконувати за умови проектування та будівництва фотоелектричних станцій в Україні, починаючи з вибору площадки для їх розміщення та закінчуючи отриманням ліщеенії на виробництво і договору на продаж отриманої електроенергії.

В роботі описано розроблення методики визначення техніко-економічної доцільності розміщення площадок фотоелектричних станиій та їх потужностей з урахуванням екологічних аспектів по регіонах Украйни. Ця методика є результатом системного наукового аналізу покрокових дій за умови проектування, будівництва та введення в експлуатацію фотоелектричної станції в Україні з урахуванням та дотриманням всіх законодавчих та технічних вимог, щчо діють на даний час в намій краӥні, починаючи з вибору площзади під будівництво ФЕС і закінчуючи отриманням лічензії на виробництво $і$ договору на продаж отриманої електроенергії. Методика для зручності користування виконана у вигляді таблиці, де в логічній послідовності розташовано пункти дій (робіт), які необхідно виконати, з поясненнями та посиланнями на діючі законодавчі та нормативні документи та отриманими результатами за кожним із пунктів.

В роботі описано алгоритм створення карт-схем для кожної із областей Украйни з відображенням на них перспективних ділянок під будівництво фотоелектростаниій з короткою їх характеристикою та можливістю приєднання до електричної мережі. Розробленню карт-схем передує аналіз стану електроенергетичної інфраструктури в районі поблизу наміченої до використання під розміщення фотоелектростаниії земельної ділянки, який необхідний також крім усього і для визначення оптимального розташування генеруючих потужностей виробництва електричної енергії. Розроблені карти-схеми дають наглядне уявлення щодо запропонованих площадок під будівництво фотоелектростанцій та щьодо можливостей їх приєднання до електричної мережі. Бібл. 9, табл.1, рис. 1.

Ключові слова: геліоенергетичний потенщіал, фотоелектрична станщія, генерація електричної енергії, площадка.

\section{FEATURES OF DETERMINATION OF RATIONAL SITES FOR PLACEMENT OF PHOTOVOLTAIC PLANTS IN UKRAINE} L. Kyrnas, V. Pundiev, V. Ryeztsov, corresponding member of the NAS of Ukraine, T. Surzhyk, candidate of technical science,
V. Shevchuk, I. Sheiko

Institute of Renewable Energy, NAS of Ukraine 02094, 20A Hnata Khotkevycha Street, Kyiv, Ukraine

The purpose of the work is to systematize and streamline the actions and main provisions taking into account the existing regulatory documents that must be fulfilled in the design and construction of photovoltaic plants in Ukraine, starting with the selection of the site for their placement and ending with obtaining a license for production and a contract for the sale of electricity.

The paper describes the development of a methodology for determining the feasibility of placement of sites of photovoltaic plants and their capacities taking into account the environmental aspects of the regions of Ukraine. This technique is the result of systematic scientific analysis of step-by-step actions in the design, construction and commissioning of a PV plants in Ukraine, taking into account and complying with all the legislative and technical requirements currently in force in our country, starting with the choice of the site for the construction of the PV plants and ending with obtaining a license for production and a contract for the sale of received electricity. The methodology for ease of use is made in the form of a table, in which the logical sequence contains the items of action (works) to be executed, with explanations and references to the existing legislative and regulatory documents and the results obtained for each of the points.

The paper describes an algorithm for mapping schemes for each of Ukraine's regions, with the projection of perspective sites for the construction of PV plants with a short description of them and the possibility of joining-up to the grid. The development of the chartdiagrams is preceded by an analysis of the state of the electric energy infrastructure in the vicinity of the planned land use for the location of a PV plants, which is also needed, in addition to all, to determine the optimal location of generating power generation capacities. The developed charts give a clear idea of the proposed sites for the construction of photovoltaic plants and the possibilities of their connection to the electrical grid. Ref. 9, tabl.1, fig. 1.

Keywords: solar energy potential, photovoltaic plants, generation of electric energy, site.

(С Л.А. Кирнос, В.О. Пундєв, В.Ф. Рєзцов, Т.В. Суржик, В.І. Шевчук, І.О. Шейко, 2019

Відновлювана енергетика. 2019. № 2 


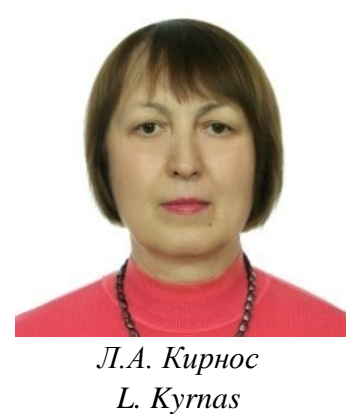

L. Kyrnas

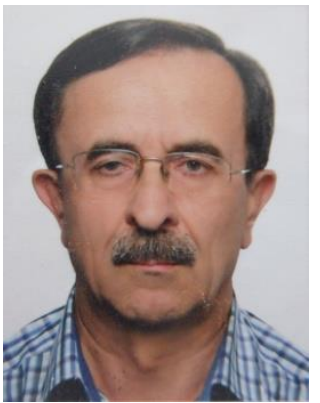

B.A. Пундєв

V. Pundiev

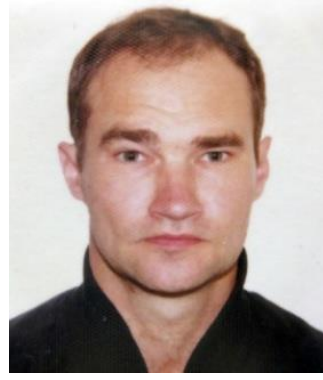

B.I. Шевчук

V. Shevchuk

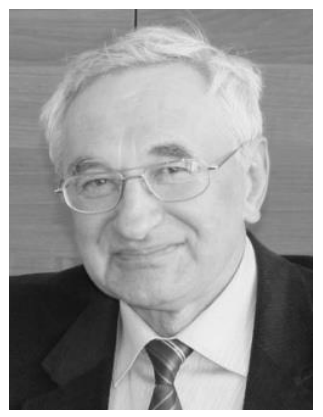

B.Ф. Рєзиов

V. Rieztsov
Відомості про автора: головний архітектор проектів відділу сонячної енергетики в Інституті відновлюваної енергетики НАН України; кваліфікаційний сертифікат №002053 «Архітектурно-об"ємне проектування»; кваліфікаційний сертифікат №002092 «Розроблення містобудівної документації».

Освіта: Київський інженерно-будівельний інститут, архітектурний факультет, фах - архітектор. Наукова сфера: енергоефективність архітектурно-будівельних об"єктів сонячної енергетики. Публікації: 5.

ORCID: 0000-0003-2503-3071

Контакти: +38 (067) 649-06-68

e-mail: larakirnos@gmail.com

Відомості про автора: науковий співробітник відділу сонячної енергетики в Інституті відновлюваної енергетики НАН України.

Освіта: Ворошиловградський машинобудівельний інститут, факультет електромашинобудування, спеціальність - електричні машини та апарати.

Наукова сфера: відновлювана енергетика, зокрема - сонячна енергетика.

Публікації: 25.

ORCID:0000-0003-3750-8812

Контакти: +38 (044) 206-28-09

e-mail: renewable@ukr.net

Відомості про автора: науковий співробітник відділу сонячної енергетики в Інституті відновлюваної енергетики НАН України.

Освіта: Київський політехнічний інститут, електротехнічний факультет, спеціальність - електричні станції.

Наукова сфера: відновлювана енергетика, зокрема - сонячна фотоенергетика.

Публікації: 40.

ORCID: 0000-0002-4176-7799

Контакти: +38 (044) 206-28-09

e-mail: renewable@ukr.net

Відомості про автора: чл.-кор. НАН України, докт. техн. наук, професор, заступник директора 3 наукових питань, завідувач відділу сонячної енергетики в Інституті відновлюваної енергетики НАН України.

Освіта: Харківський авіаційний інститут, факультет двигунів літальних апаратів, спеціальність - інженер-механік.

Наукова сфера: відновлювана енергетика.

Публікації: 306, 5 монографій, 20 патентів.

ORCID: 0000-0003-2926-1733

Контакти: +38 (044) 206-28-09

e-mail: renewable@ukr.net
Autor information: chief architect of the solar energy projects Department at the Institute of Renewable Energy of the National Academy of Sciences of Ukraine; qualification certificate №002053 "Architectural-design", qualification certificate №002092 "Development of cityplanning documentation".

Education: Kyiv Engineering and Building Institute, Faculty of Architecture, specialty architect.

Research area: Energy efficiency of architectural and construction objects of solar energy.

Publications: 5.

ORCID: 0000-0003-2503-3071

Contacts: +38 (067) 649-06-68

e-mail: larakirnos@gmail.com

Autor information: Research Associate of Solar Power Engineering Department of Institute of Renewable Energy at NAS of Ukraine.

Education: The Voroshilovgrad Machine-Building Institute in Electrical Machines and Devices.

Research area: renewable power in particular solar power.

Publications: 25

ORCID:0000-0003-3750-8812

Contacts: +38 (044) 206-28-09

e-mail: renewable@ukr.net

Autor information: research associate of Solar Power Engineering Department of Institute of Renewable Energy at NAS of Ukraine.

Education: The Kyiv Polytechnic Institute in Power Plants.

Research area: renewable power, in particular photovoltaics.

Publications: 40.

ORCID: 0000-0002-4176-7799

Contacts: +38 (044) 206-28-09

e-mail: renewable@ukr.net

Autor information: corresponding member of NAS of Ukraine, doctor of technical sciences, professor, deputy director of research, head of Solar Energy Department, Institute of Renewable Energy of the National Academy the Sciences of Ukraine. Education: Kharkiv Aviation Institute, Faculty of Aircraft Engine Engines, speciality - mechanical engineer.

Research area: renewable energy.

Publications: 306, 5 monographs, 20 patents.

ORCID: 0000-0003-2926-1733

Contacts: +38 (044) 206-28-09

e-mail: renewable@ukr.net 


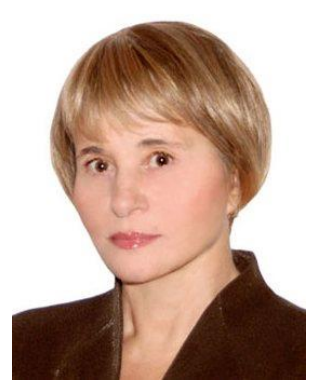

T.B. Суржик T. Surzhyk

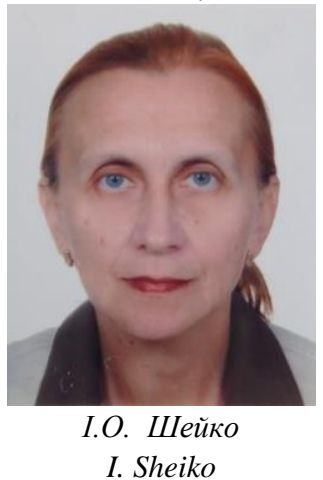

Відомості про автора: кандидат технічних наук, вчений секретар Інституту відновлюваної енергетики НАН України.

Освіта: Київський інженерно-будівельний інститут, спеціальність - теплогазопостачання та вентиляція.

Наукова сфера: відновлювана енергетика.

Публікації: 186, 25 монографії, 26 патентів.

ORCID: 0000-0002-1418-7748

Контакти: +38 (044) 206-28-09

e-mail: renewable@ukr.net

Відомості про автора: провідний інженер відділу сонячної енергетики в Інституті відновлюваної енергетики НАН України.

Освіта: Київський політехнічний інститут, факультет автоматики та приладобудування, спеціальність - електронні обчислювальні машини. Наукова сфера: відновлювана енергетика, зокрема - сонячна енергетика.

Публікації: 3.

ORCID: 0000-0002-5770-3677

Контакти: +38 (044) 206-28-09

e-mail: renewable@ukr.net
Autor information: candidate of science, science secretary in the Institute of Renewable Energy of the National Academy the Sciences of Ukraine Education: Kyivs Engineering Building - Institute, specialty - gas-heating and ventilation

Research area: renewable energy.

Publications: 186, 25 monographs, 26 patents.

ORCID: 0000-0002-1418-7748

Contacts: +38 (044) 206-28-09

e-mail: renewable@ukr.net

Autor information: leading associate of Solar Power Engineering Department of Institute of Renewable Energy at NAS of Ukraine.

Education: Kiev Polytechnic Institute, Faculty of Automation and Electrical Equipment, specialty electronic machined.

Faculty of Automation and Instrumentation, specialty - electronic computers.

Research area: renewable power in particular solar power.

Publications: 3 .

ORCID: 0000-0002-5770-3677

Contacts: +38 (044) 206-28-09

e-mail: renewable@ukr.net
Перелік використаних позначень та скорочень:

ВДЕ - відновлювані джерела енергії

ДП - державне підприємство

ДСТУ - Державний стандарт України

ГАЕС - гідроакумулююча електростанція

ЗУ - Закон України

МВт - мегават

К3 - коротке замикання

Вступ. Сучасний розвиток енергетики на основі відновлюваних джерел енергії (ВДЕ) в Україні відбувається стрімкими темпами. Так доля виробленої за допомогою ВДЕ електроенергії в загальному енергобалансі країни в 2017 році становила $1,2 \%$; в 2018 році - 1,7\% (У 2018 році до Української енергосистеми під'єднано 849 МВт нових потужностей відновлювальних джерел енергіï, 3 них на сонячну енергетику припадає 752 МВт [4]), а за прогнозами експертів в 2019 році буде $2,5 \%$. В структурі цієї електричної енергії частка, що відноситься до фотоенергетики, становить 55-60\%.

Такий швидкий розвиток фотоенергетики в Україні останнім часом відбувається як за рахунок впровадження нових більш ефективних i економічних технологій і матеріалів, так і завдяки забезпеченню державного стимулювання. Таким заохочуючим фактором в Україні $\epsilon$ «зелений» тариф на продаж електричної енергії, яка виробляється промисловими наземними фотоелектричними станціями (ФЕС) та установками на дахах будівель. Запровадження «зеленого» тарифу в Україні виявилось, як показує сьогодення, $\epsilon$ досить вдалим i ефективним стимулятором та
КТП - комплектна трансформаторна підстанція

ОЕС - об'єднана енергетична система

ПС - підстанція електрична

PEM - районна електрична мережа

ТЕС - теплоелектростанція

ТУ - технічні умови

ФЕС - фотоелектрична станція

дало можливість залучити кошти закордонних та вітчизняних інвесторів до розвитку цього напрямку відновлюваних джерел енергії.

Але стрімке та часом бурхливе будівництво та введення в дію ФЕС відбувалось та відбувається і зараз без необхідного відповідного аналізу та врахування комплексу хоча б основних факторів і критеріїв, які можуть впливати на будівництво та експлуатацію фотоелектростанцій. А це може призвести до завдання безповоротної шкоди довкіллю та до інших негативних наслідків, не говорячи вже про можливі безпідставні (які можна було б уникнути) втрати генерування, а відповідно, і прибутку власником і державою та інших можливих негативних впливів.

Постановка завдання. Авторами цієї статті в рамках роботи [1] була поставлена задача виконання дослідження щодо визначення раціональних площадок розміщення фотоелектричних станцій в Україні із урахуванням екологічних аспектів та оптимального розташування генеруючих потужностей виробництва електричної енергії.

Виклад основного матеріалу. Суть роботи полягала в розробленні методики визначення техніко-економічної доцільності розміщення пло- 
щадок ФЕС та їх потужностей 3 урахуванням екологічних аспектів по регіонах України. В процесі розробки методики проведено детальний аналіз існуючої офіційної інформації по ряду вищевказаних факторів та інформації, отриманої шляхом направлення запитів та отриманих на них відповідей 3 областей та районів України. При цьому кожне 3 положень методики мало під собою науково-технічне обгрунтування та логічне пояснення.

За умови розробки цієї методики було враховано широкий спектр основних факторів:

- геліоенергетичний потенціал (загальний рівень сумарної сонячної радіації, що надходить на квадратний метр горизонтальної поверхні на протязі року, та тривалості сонячного сяйва в годинах на рік) по областям України, що є одним 3 основних критерїв за умови вибору площадок для розміщення ФЕС. При розгляді цього питання були використані теоретичні напрацювання щодо визначення оптимального кута нахилу фотобатарей до горизонту, що є важливим для попереднього теоретичного розрахунку виробітку електроенергії протягом року [2];

- раніше розроблені цим же колективом рекомендації щодо визначення перспективних площадок розташування ФЕС в Україні з урахуванням проблеми охорони довкілля;

- наявність та стан електричних підстанцій (ПС) та комплектних трансформаторних підстанцій (КТП), їх завантаженість, потреба в реконструкції, модернізації, які знаходяться поблизу вибраних площадок або будівництві нових;

- стан магістральних та розподільчих мереж (їх наявність, розгалуженість та завантаженість, потреба в реконструкції, модернізації або будівництві нових);
- наявність компенсуючих потужностей (TEC, ГАЕС тощо);

- потреба в розміщенні нових електрогенеруючих потужностей;

- наявність необхідної інфраструктури тощо.

Як вже наголошувалося вище, при розробленні методики були використані напрацювання минулих років за цим напрямком - рекомендації щодо визначення перспективних площадок розташування ФЕС в Україні з врахуванням проблеми охорони довкілля (у тому числі флори, фауни) та об'єктів культурної спадщини тощо [3, 5 - 9].

В цих рекомендаціях використані наявні матеріали по визначенню перспективних площадок розташування ФЕС в Україні, а також враховані недоліки, що були виявлені щодо площадок ФЕС, які вже введені в експлуатацію в Україні, а саме:

- нераціональні режими експлуатації ФЕС, які розміщені в центральних, західних та східних областях України, що сприяє значному збільшенню розмірів площадок ФЕС - до $20 \%$;

- відсутність механізму контролю стану культурної та археологічної спадщини при проведенні будівельних та земляних робіт на площадці ФЕС. Останнім часом об'єкт будівництва, який знаходиться поза межами вже існуючих заповідних та охоронних зон пам'яток або історичних місць, зазвичай не погоджувався 3 органами охорони культурної спадщини, тобто під охороною залишається зовсім незначний їі відсоток тощо.

Методика щодо визначення технікоекономічної доцільності розміщення площадок ФЕС та їх потужностей із врахуванням екологічних аспектів по регіонах України представлена в таблиці 1. Визначення площадок ФЕС за цією методикою проводиться в 2 етапи.

Таблиця 1 - Методика визначення техніко-економічної доцільності розміщення площадок ФЕС та їх потужностей 3 урахуванням екологічних аспектів по регіонах України

Table 1 - Methodology for determining the feasibility of placing for photovoltaic plants sites and their facilities taking into account environmental aspects in the regions of Ukraine

\begin{tabular}{|c|c|c|}
\hline \begin{tabular}{|l} 
№ \\
3/ח
\end{tabular} & Найменування заходу & $\begin{array}{c}\text { Нормативне джерело, методи визначення } \\
\text { показників }\end{array}$ \\
\hline 1 & 2 & 3 \\
\hline \multicolumn{3}{|c|}{ Етап 1 - попереднє визначення техніко-економічної доцільності розміщення площадок ФЕС } \\
\hline 1 & $\begin{array}{l}\text { Наявність (пошук) земельної ділянки з наміром її використання в } \\
\text { якості площадки для будівництва ФЕС в межах вибраного регіону } \\
\text { (області) України та попередня оцінка геліоенергетичного ресурсу в } \\
\text { місці її розташування. Визначається: загальний рівень сумарної со- } \\
\text { нячної радіації, що надходить на м² горизонтальної поверхні пло- } \\
\text { щадки протягом року; тривалість сонячного сяйва (в год. на рік). }\end{array}$ & $\begin{array}{l}\text { Попереднє середньомісячне (за порами } \\
\text { року) та середньорічне значення сонячного } \\
\text { випромінювання, визначається за усеред- } \\
\text { неними довгостроковими даними згідно з } \\
\text { ДСТУ 4885-2007. Допускається викорис- } \\
\text { тання даних сонячної бази випромінюван- } \\
\text { ня: PVGIS-CM SAF. }\end{array}$ \\
\hline
\end{tabular}




\begin{tabular}{|c|c|c|}
\hline 1 & 2 & 3 \\
\hline 2 & $\begin{array}{l}\text { Попередній розрахунок потужності ФЕС, яка може бути розміще- } \\
\text { на на підібраній земельній площадці та теоретичний розрахунок } \\
\text { помісячних графіків електропостачання від ФЕС для підготовки } \\
\text { матеріалів запиту до районних електромереж (РЕМ ) щодо видачі } \\
\text { технічних умов (ТУ) на приєднання до мережі та розгляд ймовір- } \\
\text { них точок підключення. }\end{array}$ & $\begin{array}{l}\text { Сонячна база випромінення: PVGIS-CM } \\
\text { SAF. www.alter-energo.com.ua. }\end{array}$ \\
\hline 3 & $\begin{array}{l}\text { Звернення до РЕМ з метою отримання попередньої інформації для } \\
\text { оцінки стану наявної електротехнічної інфраструктури щодо ви- } \\
\text { значення перспективної можливості приєднання ФЕС до електри- } \\
\text { чних мереж ОЕС України та передача від станції виробленої елек- } \\
\text { троенергії: } \\
\text { 1) наявність електричних підстанцій та ліній електропередачі, від- } \\
\text { стані до них та спроможності їх приймати генеровану потужність, } \\
\text { у т.ч. характеристики ліній електропередачі та можливість сумі- } \\
\text { щення їх з параметрами ФЕС, що прогнозуються (потужність, на- } \\
\text { пруга, частота, переріз струмопровідних жил, тривалий струм для } \\
\text { кабелів та проводів, розрахунковий струм короткого замикання } \\
\text { (КЗ) тощо); } \\
\text { 2) оцінка стану іншої інфраструктури, а саме: під'їзних та магіст- } \\
\text { ральних автошляхів, залізничних колій і відстаней до них, інжене- } \\
\text { рних мереж (тепло- водопостачання, каналізації тощо) та відстаней } \\
\text { до них, розташованих поруч населених пунктів тощо. }\end{array}$ & $\begin{array}{l}\text { 3У № 575/97- ВР від 16.10.1997 р.; СНиП } \\
\text { 3.05.06-85, ДНАОП 1.1-10-1,01-97 «Прави- } \\
\text { ла безпечної експлуатації електроустано- } \\
\text { вок». } \\
\text { Візуальне обстеження. Карти енергосистем } \\
\text { України для передачі електроенергії в ОЕС } \\
\text { України та перелік наявних трансформато- } \\
\text { рних підстанцій з інформацією щодо їх } \\
\text { завантаженості (за інформацією обленер- } \\
\text { го). Національний атлас України. Сайти } \\
\text { обленерго. ГОСТ 13109-97, ДСТУ ЕN } \\
\text { 50160:2014, ДСТУ ЕN 61000.3-2:2015. } \\
\text { ДБН В.1.2-2:2006, ДБН В.1.2-5:2007, ДБН } \\
\text { В.1.2-6-2008. }\end{array}$ \\
\hline 4 & $\begin{array}{l}\text { 3) оцінка впливу будівництва і діяльності ФЕС на флору і фауну, а } \\
\text { саме перевірка потенційної площадки на відсутність на ній шляхів } \\
\text { перельоту та міграції птахів та міграції тварин, а також на відсут- } \\
\text { ність на ній рідкісних видів дерев та інших рослин, занесених до } \\
\text { Червоної книги України тощо; } \\
\text { 4) попередня оцінка впливу діяльності ФЕС на навколишнє приро- } \\
\text { дне середовище включаючи вплив на ландшафти, поверхневі і } \\
\text { підземні водні ресурси, геологію, приземний шар атмосфери, клі- } \\
\text { мат та мікроклімат, грунт, рослинний і тваринний світ, а також } \\
\text { здоров’я людини; } \\
\text { 5) оцінка впливу діяльності ФЕС на техногенне, соціальне середо- } \\
\text { вище району, а також історичні та заповідні території і об’єкти та } \\
\text { археологічної і культурної спадщини. Перевірка потенційної пло- } \\
\text { щадки на невходження ії до земель заповідників, національних } \\
\text { парків та інших природоохоронних земель, визначених законодав- } \\
\text { ством України. }\end{array}$ & $\begin{array}{l}\text { ЗУ №1268-ХІІ від 26.06.1991, ДБН В.1.2-8- } \\
2008 . \\
\text { Топографічні карти Укркартгеофонду } \\
\text { М 1:10000 або М 1:25000 з розбивкою та } \\
\text { прив'язкою точок геофізичних спостере-- } \\
\text { жень; 3У № } 2480 \text { від 09.07.2010; 3У № } \\
\text { 0962 від 19.06.2003; 3У № 2768-111 від } \\
\text { 25.10.2001; ГОСТ 25100:2011; ГОСТ 17.4.3 } \\
\text { - 02-85/2003. } \\
\text { Візуальний аналіз та аналіз архівних і фон- } \\
\text { дових матеріалів з метою з'ясування інже- } \\
\text { нерно-геологічних і гідрогеологічних умов } \\
\text { району робіт. Топографічні карти Укркарт- } \\
\text { геофонду М 1:10000 або М 1:25000 з роз- } \\
\text { бивкою та прив'язкою точок геофізичних } \\
\text { спостережень; ДБН А.2.2-3:2012; ДБН } \\
\text { В.1.1-3-97; ГОСТ 17.1.3.06-86 (2003). } \\
\text { Топографічні карти; Національний атлас } \\
\text { України; ЗУ № 0591 від 09.04.1999; ЗУ № } \\
\text { 3041 від 03.03.1993; ДБН А.2.2-1-2003. }\end{array}$ \\
\hline 5 & $\begin{array}{l}\text { Оцінка супутніх факторів - наявність чи будівництво поблизу } \\
\text { площадки під ФЕС: аеродромів, автомобільних шляхів, спору- } \\
\text { дження будівель чи інших об'єктів, які можуть взаємно негативно } \\
\text { впливати. }\end{array}$ & $\begin{array}{l}\text { Профільні топографічні карти; Національний } \\
\text { атлас України; консультація в районних (об- } \\
\text { ласних) адміністраціях та в головних управ- } \\
\text { ліннях Держземагентств областей та відділів } \\
\text { Держземагентств районів (по областях та } \\
\text { районах України). }\end{array}$ \\
\hline
\end{tabular}




\begin{tabular}{|c|c|c|}
\hline 1 & 2 & 3 \\
\hline 6 & $\begin{array}{l}\text { Оцінка економічних факторів на сьогодення, а саме: рівень інфля- } \\
\text { ції; динаміка зростання цін на електроенергію; собівартість вироб- } \\
\text { леної електроенергії в залежності від інтенсивності сонячного ви- } \\
\text { промінювання по регіонах; динаміка зміни коефіцієнта дисконту- } \\
\text { вання; наявність та стан банків з пільговим кредитуванням тощо. } \\
\text { Ці фактори впливають на ціну проекту, на швидкість його вико- } \\
\text { нання та будівництво ФЕС. }\end{array}$ & $\begin{array}{l}\text { За даними Держкомстату України; ДП } \\
\text { «НЕК «Укренерго»; Національної комісії, } \\
\text { що здійснює державне регулювання у сфе- } \\
\text { рах енергетики та комунальних послуг } \\
\text { (НКРЕКП); Національного банку України; } \\
\text { Міністерства фінансів України та Мініс- } \\
\text { терства економічного розвитку та торгівлі } \\
\text { України тощо. }\end{array}$ \\
\hline 7 & $\begin{array}{l}\text { Визначення техніко-економічних показників площадки, оцінка собі- } \\
\text { вартості виробленої електроенергії та прийняття попереднього рі- } \\
\text { шення щодо доцільності використання площадки під ФЕС. Розробка } \\
\text { ТЕО проекту будівництва ФЕС.* }\end{array}$ & $\begin{array}{l}\text { ГКД 340.000.001.1995; } \\
\text { ГКД 341.003.003.006.2000. }\end{array}$ \\
\hline
\end{tabular}

Етап 2. Остаточне визначення техніко-економічної доцільності розміщення площадок ФЕС

Прийняття остаточного рішення щодо техніко-економічної доцільності розміщення площадки ФЕС та оформлення пакету документів на проектування, будівництво та введення в експлуатацію станції:

1) реєстрація юридичної особи; **

2) оформлення права на землю обраної ділянки землі; ***

3) отримання технічних умов і укладання договору про приєднання до мережі; ****

4) розробка проектної документації на приєднання до мережі; *****

5) будівництво і введення в експлуатацію

електроустановок інженерного забезпечення;

6) розробка проектної документації на будівництво ФЕС;

7) будівництво і введення в експлуатацію електростанції;

8) отримання ліцензії на виробництво електроенергії; ******

9) підтвердження української складової;

10) встановлення «зеленого» тарифу;

11) членство в Оптовому ринку електроенергії (ОРЕ) - укладення договору з ДП «Енергоринок»;

12) договір на продаж електроенергії.

http://saee.gov.ua/documents/green-card.pdf; ДБН А.2.2-3-2012; СН 441-72.

Постанова НКРЕКП №32 від 17.01.2013

«Про затвердження правил приєднання електроустановок до електричних мереж».

Постанова КМУ №753 від 29 квітня 1999

року.

Постанова НКРЕКП № 1421 від 02.11.2012.

Примітки: * До складу бізнес-плану, зазвичай, включаються такі розділи: інформація про власника або ініціатора проекту; детальна інформація про проект будівництва об'єкта; інформація про майданчик розміщення об'єкта; розрахунок вартості реалізації проекту; прогноз доходів і витрат за проектом; рух грошових коштів на весь період дії «зеленого тарифу»; розрахунок окупності з урахуванням різних варіантів розвитку подій; розрахунок фінансових та інвестиційних показників проекту; SWOT-аналіз та аналіз чутливості; аналіз основних ризиків і шляхів їх мінімізації; фінансова модель проекту (два варіанти: 100 \% власний капітал і для випадку позикового фінансування).

** Можна уникнути проходження цього етапу, якщо є можливість використовувати вже існуючу юридичну особу, або вести господарчу діяльність в якості фізичної особи-підприємця.

*** ФЕС можна розмістити як на власній земельній ділянці, так і на ділянці, отриманій у користування (оренду). При цьому така земельна ділянка повинна входити до категорії (мати цільове призначення) «землі енергетики».

Відведення земельної ділянки включає такі етапи та документи: оптимальний вибір розташування під конкретні потреби; оформлення дозвільних документів; проект землеустрою та його експертиза; нормативна грошова оцінка та ії експертиза; інтеграція 3 містобудівною документацією; інтеграція 3 промисловим проектуванням; оформлення прав власності/користування; отримання необхідних технічних умов для відповідних потреб; підготовка до проведення юридичного duе diligence.

**** Якщо встановлена потужність станції дорівнює або перевищує 70 МВт, то слід звернутися до ДП «НЕК «Укренерго». Якщо встановлена потужність $\epsilon$ меншою ніж $10 \mathrm{MBT}$ - то до місцевої електропередавальної організації (обленерго). У випадку приєднання установок потужністю від 10 до 70 МВт можна звертатися до будь-якої із зазначених вище організацій. Для отримання технічних умов заявникові необхідно надати до електропередавальної організації наступні документи: заяву про приєднання (за типовою формою); ситуаційний план із зазначенням розміщення ФЕС і викопіювання 3 генерального плану у масштабі 1:2000 або 1:5000 із зазначенням місця розташування станції або земельної ділянки; копію довіреності на право укладання договорів; копію документа, що підтверджує право власності або користування об'єктом або, у випадку відсутності об'єкта, право власності чи користування земельною ділянкою; копію свідоцтва платника податків на додану вартість (ПДВ) або свідоцтва про сплату єдиного (фіксованого) податку.

***** Проектну документацію розробляє електропередавальна організація (обленерго).

****** Для отримання ліцензії на виробництво електроенергії необхідно подати такі документи (у 5 комплектах, 13 яких нотаріально засвідчується): заява; довіреність (якщо документи подає представник); документ про внесення плати за видачу ліцензії; копія статуту (нотаріально засвідчена); опис заявленої діяльності (технічні характеристики об'єкту, що генерує енергію; схема електричних з'єднань із зазначенням приладів розрахункового обліку); документ, що підтверджує Норматив достатності власних активів суб’єктів підприємницької діяльності (копія бухгалтерської звітності Ф-№1 за звітний період); копія документа, що підтверджує право власності на потужності, що генеруються, або право користування ними (3 підтвердженням права власності третьої особи). 
Крім того в рамках цієї роботи було створено інформативні карти-схеми для кожної із областей України, які можуть бути задіяні в планах подальшого прискореного розвитку фотоенергетики в Україні. Це дасть можливість додатково залучити до будівництва ФЕС інвесторів (як вітчизняних, так і зарубіжних). На цих картах-схемах відображено потенційні площадки для розміщення фотоелектричних станцій 3 короткою їх характеристикою та можливістю приєднання до електричної мережі.

За основу карт-схем було взято інформацію щодо наявності площадок (земельних ділянок), придатних для розміщення фотоелектричних станцій по регіонах України.

Для цього були розіслано запити по областям на адреси обласних державних адміністрацій та до головних управлінь Держгеокадастру. При цьому запити вже містили в собі попередні обмежуючі вимоги до площадок, що пропонуватимуться.

Далі, отримані за результатами запитів площадки (земельні ділянки), проходили вивчення та детальний попередній аналіз 3 використанням наявної інформації та інформації, отриманої 3 відкритих доступних в Інтернеті джерел щодо загальної інфраструктури (автомобільні шляхи, залізничні станції тощо) та енергетичної (лінії електропередачі, трансформаторні підстанції тощо), та перевірку на відповідність рекомендаціям щодо визначення перспективних площадок розташування ФЕС в Україні з врахуванням проблеми охорони довкілля (у тому числі флори, фауни) та об'єктів культурної спадщини [3]. Після обробки та аналізу ці площадки, якщо вони не мали категоричних застережень щодо можливості їх використання для розміщення ФЕС, наносилися на карти-схеми відповідних областей з географічною прив'язкою до відповідної карти області та короткою інформацією: номер ділянки, площа земельної ділянки (га), відстань до найближчої електричної підстанції (км), та наявність на підстанції вільних резервних потужностей для підключення. Приклад карти-схеми з відображенням перспективних площадок під будівництво фотоелектричних станцій зображено на рис.1.

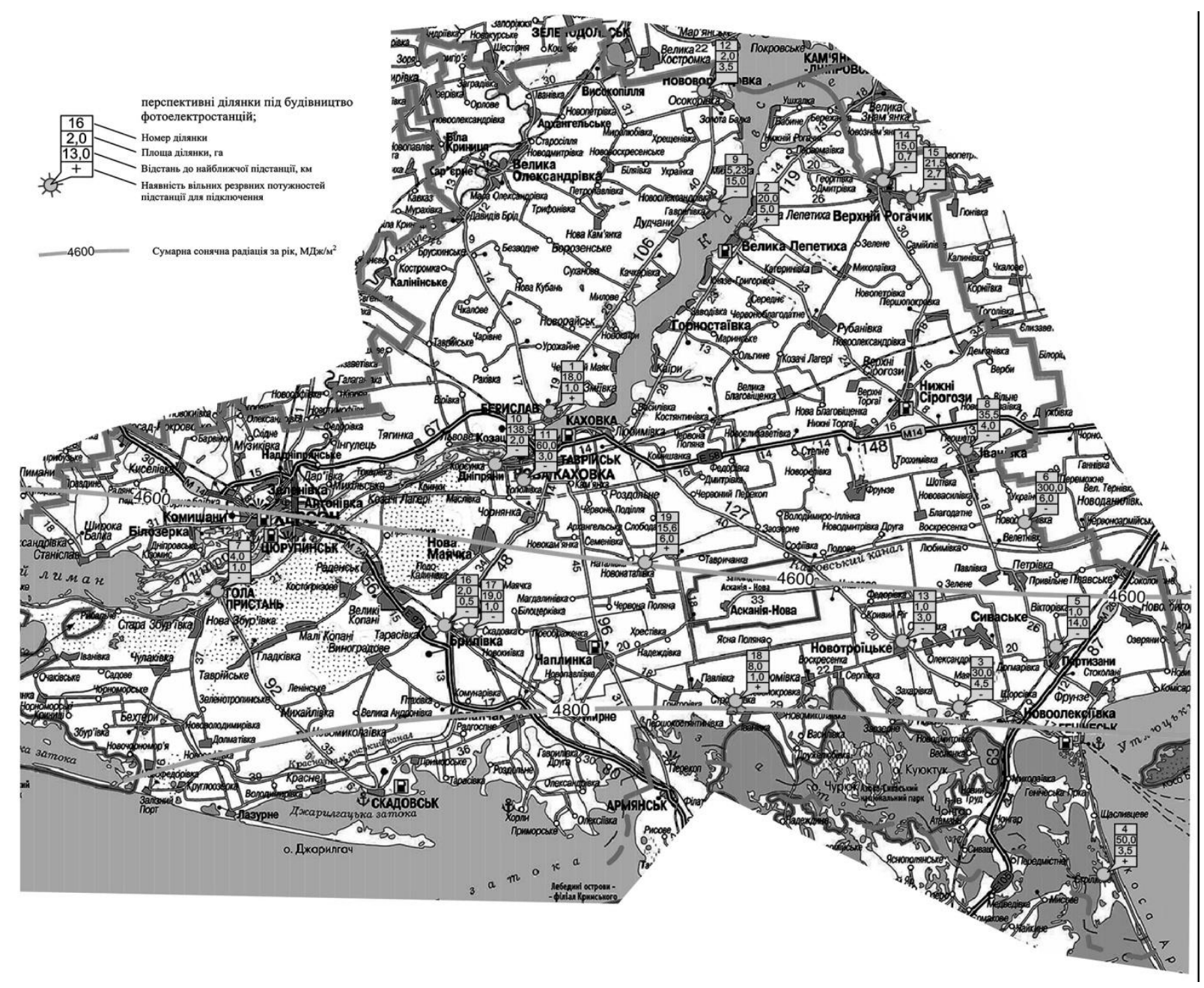

Рис.1. Карта-схема Херсонської області.

Fig.1. Map diagram of the Kherson region. 
При розробці карт-схем використано метод пошарового накладання накопиченої інформації та відображення різної за характером та призначенням інформації різними кольорами. Такий підхід до обробки та відображення інформації дає наглядне комплексне всебічне представлення щодо наявності площадок в конкретних регіонах та можливості їх використання для розміщення ФЕС 3 урахуванням всіх аспектів: охорони довкілля (у тому числі флори, фауни тощо), об'єктів культурної спадщини, геліоенергетичних ресурсів площадок, супутніх факторів, що можуть істотно впливати на вирішення питання щодо розміщення ФЕС, таких як:

- техногенне та соціальне середовище району, а також історичні та заповідні території і об'єкти;

- існування та стан інфраструктури, а саме ліній для передачі електроенергії ФЕС в національну енергосистему тощо.

Розроблені карти-схеми для кожної із областей України можуть бути задіяні в планах подальшого розвитку фотоенергетики в Україні, що дасть можливість залучити до будівництва ФЕС інвесторів (як вітчизняних, так і зарубіжних), зменшити енергетичну залежність від зовнішніх органічних енергоносіїв (природного газу, наприклад, тощо), дозволить покращити екологічну обстановку в регіоні, створити нові робочі місця та додаткові надходження в місцеві бюджети.

Висновки. В результаті виконання роботи одержано наступні результати:

1. Розроблено методику визначення технікоекономічної доцільності розміщення площадок ФЕС та їх потужностей з урахуванням екологічних аспектів по регіонах України за умови ії використання дозволить раціонально розміщувати площадки під будівництво фотоелектричних станцій по всіх регіонах України, що дасть змогу зменшити при цьому часові та економічні витрати. В методиці впорядковано і описано поетапно дії та основні положення з урахуванням діючих нормативних документів, які необхідно виконувати за умови проектування та будівництва ФЕС в Україні, починаючи з вибору площадки для їх розміщення та закінчуючи отриманням ліцензії на виробництво і договору на продаж отриманої електроенергії.

2. Карти-схеми 3 визначеними раціональними площадками розміщення ФЕС із урахуванням екологічних аспектів та оптимального розташування генеруючих потужностей для кожної області по регіонах України та з визначенням пріоритетності освоєння площадок можуть бути задіяні в планах подальшого розвитку фотоенергетики в Україні, що дасть можливість залучити до будів- ництва ФЕС інвесторів (як вітчизняних, так і зарубіжних), зменшити енергетичну залежність від зовнішніх органічних енергоносіїв (природного газу, наприклад, тощо), дозволить покращити екологічну обстановку в регіоні, створити нові робочі місця та додаткові надходження в місцеві бюджети.

1 Збірник рефератів дисертацій, НДР та ДКР № / 0218U000057 Визначення раціональних площадок розміщення фотоелектричних станцій по регіонах України із урахуванням екологічних аспектів та оптимального розташування генеруючих потужностей виробництва електричної енергії: Заключний звіт / Інститут відновлюваної енергетики НАН України; Керівник Рєзцов В.Ф. ДР 0116U006212. УДК 620.9. $153 \mathrm{c}$.

2. Гамарко А.В., Пундев В.А., Резиов В.Ф., Суржик Т.В., Шевчук В.И. Эффективность использования площадок для размещения фотоэлектрических станций. Международный научный журнал «Альтернативная энергетика и экология» (ISJAEE). 2014. №23. C. 35-39.

3. Збірник рефератів дисертацій, НДР та ДКР № 05’2018 44.10.18.0529 / 0216U005119 Розробка комплексних заходів і методичних рекомендацій зі зменшення впливу на довкілля при будівництві та експлуатації фотоелектричних станцій: Заключний звіт. Інститут відновлюваної енергетики НАН України. Керівник Рєзцов В.Ф. ДР 0113U005151. УДК 620.9. $150 \mathrm{c}$

5. Кудря С.О., Рєзиов В.Ф., Суржик Т.В., Яиенко Л.В., Душина Г.П., Васько П.Ф., Морозов Ю.П., Забарний Г.М. та ін. Атлас енергетичного потенціалу відновлюваних джерел енергії України. К. Інститут відновлюваної енергетики НАН України. 2013. $60 \mathrm{c.}$

6.Рєзцов В.Ф., Суржик Т.В., Теймуразян М.С. Аналіз розповсюдження вищих гармонійних складових напруг і струмів у кабельних лініях фотоелектричних станцій та засобів обмеження їх впливу на оточуюче середовище. Відновлювана енергетика. 2014. № 1(36). С. 36-40.

7.Пундев В.А., Шевчук В.И. Перспектива использования зоны отчуждения ЧАЭС для развития фотоэнергетики в Украине // Международный научный журнал «Альтернативная энергетика и экология» (ISJAEE). 2017. № 04-06 (216218). C. $25-32$

8. Гамарко А.В., Матвійчук О.С., Пундєв В.О., Суржик Т.В., Шевчук В.І., Яиенко В.В. ДСТУ 8328:2015 Геліоенергетика. Модулі фотоелектричні. Загальні технічні вимоги. Введено 01.07.2017. К. ДП УкрНДНЦ. 2016. 30 с.

9.Гамарко А.В., Матвійчук О.С., Пундєв В.О., Суржик Т.В., Шевчук В.І., Яиенко В.В. ДСТУ 8635:2016 Геліоенергетика. Площадки для фотоелектричних станцій. Приєднання до електроенергетичної системи. Введено 01.01.2017. К. ДП УкрНДНЦ. 2016. 52 с.

\section{REFERENCES}

1. Zbirnyk referativ dysertaciy, naukovo-doslidnykh ta doslidno-construktorskikh robit №0218U000057 Vyznachennya ratsionalnykh ploshchadok dlya rozmishchennya fotoelectrychnykh stantsiy po regionakh Ukrainy. [Collection of abstracts of dissertations, research papers and research reports № 0218U000057 Determination of rational sites for the location of photovoltaic plants in the regions of Ukraine taking into account the environmental aspects and optimal location of generating power generation capacities]: Final Report. Renewable Energy Institute of the National Academy of Sciences of Ukraine. 
Chairman Reztsov V.F. State Registration 0116U006212. UDC 620.9. 153 p. [in Ukrainian].

2. Gamarko A.V., Pundev V.A., Reztsov V.F., Surzhik T.V., Shevchuk V.I. Efectyvnict vykorystannya ploshchadok dlya rozmishchennya fotoelectrychnykh stanciy. [The Efficiency of Using Places for Placing Photovoltaic Plants].International Scientific Journal "Alternative Energy and Ecology» (ISJAEE). 2014. No. 23. Pp. 35-39. [in Ukrainian].

3. Zbirnyk referativ dysertaciy, naukovo-doslidnykh ta doslidno-construktorskikh robit № 05'2018 44.10.18.0529/ 0216U005119 Rozrobka komplexnykh zahodiv i metodychnykh recomendaciy zi zmenshennya vplyvu na dovkillya pry budivnytstvi ta expluataciyi fotoelectrychnykh stanciy. [Collection of abstracts of dissertations, research papers and scientific research institutes № 05'2018 44.10.18.0529/0216U005119 Development of complex measures and methodological recommendations for reducing the environmental impact during the construction and operation of photovoltaic plants]. Final Report. Renewable Energy Institute of the National Academy of Sciences of Ukraine. Chairman Reztsov V.F. State Registration 0113U005151. UDC 620.9. 150 p. [in Ukrainian].

5. Kudrya S.O., Reztsov V.F., Surzhik T.V., Yatsenko L.V., Dushina G.P., Vasko P.F., Morozov Yu.P., Zabarny G.M. etc. Atlas enerhetychnoho potentsialu alternatyvnoi enerhetyky $\mathrm{v}$ Ukraini. [Atlas of the energy potential of renewable energy sources in Ukraine]. K. Renewable Energy Institute of NAS of Ukraine. 2012. 60 p. [in Ukrainian].

6. Reztsov V.F., Surzhik T.V., Teimurazyan M.S. Analiz rozpovsiudzhennya vyshchykh harmoniynykh skladovykh napruh ta strumiv v cabelnyh liniyah fotoelectrychnykh stanciy ta zasobiv obmezhennya ikh vplyvu na otochuyiuche seredovyshche. [Analysis of the distribution of higher harmonic components of voltages and currents in cable lines of photovoltaic stations and means of limiting their impact on the environment]. Vidnovluvana energetika. 2014. No. 1(36). Pp. 36-40. [in Ukrainian].

7. Pundev V.A., Shevchuk V.I. Perspectyvy vycorystannya Chernobylskoy zony $\mathrm{z}$ metoiu rozvytku fotoenergetyky $\mathrm{v}$ Ukraini. [Perspective of the use of the Chernobyl Exclusion Zone for the development of photovoltaic in Ukraine]. International Scientific Journal «Alternative Energy and Ecology». 2017. No. 04-06 (216-218). Pp.25-32. [in Ukrainian].

8. Gamarco A.V., Matviychuk O.S., Pundev V.O., Surzhik T.V., Shevchuk V.I., Yatsenko V.V. DSTU 8328: 2015 Helioenergetyka. Moduli fotoelectrychni. Zagalni tekhnichni vymogy. [Solar energy. Photoelectric modules. General technical requirements]. Entered on 07.01.2017. K. DP UkrNDNTS. 2016. 30 p. [in Ukrainian].

9. Gamarko A.V., Matviichuk O.S., Pundev V.O., Surzhik T.V., Shevchuk V.I., Yatsenko V.V. DSTU 8635:2016 Helioenergetyka. Ploshchadki dlya rozmishchennya fotoelectrychnykh stanciy. Pryednannya do electroenergetychnoi systemy. [Solar energy. Places for photovoltaic plants. Accession to the electric power system]. Entered 01.01.2017. K. State Enterprise UkrNDNTS. 2016. 52 p. [in Ukrainian].

\section{ОСОБЕННОСТИ ОПРЕДЕЛЕНИЕ РАЦИОНАЛЬНЫХ ПЛОЩАДОК ДЛЯ РАЗМЕЩЕНИЯ ФОТОЭЛЕКТРИЧЕСКИХ СТАНЦИЙ В УКРАИНЕ}

Л.А. Кырнос, В.А. Пундев, В.Ф. Резцов, чл.-корр. НАН Украины, Т.В. Суржик, канд. техн. наук, В.И. Шевчук, И.О. Шейко

Институт возобновляемой энергетики НАН Украины, 02094, Киев, ул. Гната Хоткевича 20a,

Целью работы является систематизачия и упорядочение действий и основных положений с учетом действуюших нормативных документов, которые необходимо выполнять при условии проектирования и строительства фотоэлектрических станций в Украине, начиная с выбора площадки для их размещения и заканчивая получением лицензии на производство и договора на продажу полученной электроэнергии.

В работе описана разработка методики определения технико-экономической иелесообразности размещения пломадок фотоэлектрических станиий и их мочностей с учетом экологических аспектов по регионам Украины. Эта методика является результатом системного научного анализа пошаговых действий при проектировании, строительстве и вводе в эксплуатацию фотоэлектрической станиии в Украине с учетом и соблюдением всех законодательных и технических требований, действуюших в настоящее время в нашей стране, начиная с выбора пломадки под строительство ФЭС и заканчивая получением лицензии на производство и договора на продажу полученной электроэнергии. Методика для удобства пользования выполнена в виде таблииы, где в логической последовательности расположены пункты действий (работ), которые необходимо выполнить, с пояснениями и ссылками на действующие законодательные и нормативные документы и полученными результатами по каждому из пунктов.

В работе описан алгоритм создания карт-схем для каждой из областей Украины с отображением на них перспективных участков под строительство фотоелектростанций с короткой их характеристикой и анализом возможности присоединения к электрической сети. Разработке картсхем предшествует анализ электроэнергетической инфраструктуры в районе вблизи намеченного к использованию под размещение фотоелектростанции земельного участка, который необходим также, кроме всего, и для определения оптимального расположения генерирующих мощчностей производства электрической энергии. Разработанные карты-схемы дают наглядное представление о предлагаемых площадках под строительство фотоелектростанций и о возможностях их присоединения к электрической сети. Библ. 9, табл.1, рис. 1 .

Ключевые слова: гелиоэнергетический потенциил, фотоэлектрическая станиия, генерация электроэнергии, площзадка. 